\title{
POLA SEBARAN MATERIAL PADATAN TERSUSPENSI (MPT) DI PERAIRAN MUARA SUNGAI LA BALANO KABUPATEN MUNA
}

\author{
Distribution Pattren of Total Suspended Solid (TSS) in the Estuary of La Balano \\ Muna Regency
}

\author{
Safarudin $^{1}$, La Ode Muh. Yasir Haya ${ }^{2}$ dan Amadhan Takwir ${ }^{3}$ \\ ${ }^{1}$ Mahasiswa Jurusan Ilmu Kelautan, \\ Fakultas Perikanan dan Ilmu Kelautan, Universitas Halu Oleo. \\ Jl. H.E.A Mokodompit Kampus Hijau Bumi Tridharma Anduonohu Kendari 93232, Telp/Fax: (0401) 3193782 \\ ${ }^{2}$ Surel: lmyasir.haya@gmail.com \\ ${ }^{3}$ Surel: awhier@gmail.com
}

\begin{abstract}
Abstrak
Perairan di sekitar Muara Sungai La Balano terdapat kegiatan pemanfaatan ruang seperti pemukiman, budidaya tambak, perkebunan dan pertanian yang diperkirakan berperan besar pada terjadinya penurunan kualitas air. Konsentrasi Material Padatan Tersuspensi (MPT) yang berlebihan di muara sungai dapat menyebabkan kekeruhan dan ancaman pendangkalan. Tujuan dari penelitian ini adalah untuk mengetahui konsentrasi MPT, perubahan pola arus dan pola sebaran MPT saat kondisi pasang dan surut di Perairan Muara Sungai La Balano Kab. Muna. Metode penentuan titik stasiun menggunakan purposive sampling. Pengambilan data sampel air dan pengukuran parameter fisika oseanografi dilakukan saat kondisi air pasang dan air surut. Analisis sampel MPT menggunakan metode Gravimetri. Peta Pola sebaran MPT diinterpolasi menggunakan metode Inverse Distance Weighted (IDW). Hasil penelitian menunjukkan bahwa konsentrasi MPT di Perairan Muara Sungai La Balano saat kondisi pasang berkisar antara 13.90 - $14.46 \mathrm{mg} / \mathrm{l}$ dan kondisi surut berkisar 13.87 - $14.50 \mathrm{mg} / \mathrm{l}$, dengan pola arus yang didominasi oleh arus pasut yaitu terjadi bolak-balik. Pola sebaran MPT di Muara Sungai La Balano terlihat bahwa saat kondisi pasang terjadi penumpukan sedimen di sekitar jety dan saat kondisi surut terjadi penumpukan sedimen di muara sungai. Berdasarkan hasil penelitian dapat disimpulkan bahwa sebaran MPT mengikuti pergerakan arus pasang surut sedangkan konsentrasinya lebih besar bersumber dari daratan.
\end{abstract}

Kata Kunci : Material Padatan Tersuspensi, Pasang Surut, Pola Sebaran, Muara Sungai La Balano

\begin{abstract}
The waters around of La Balano Estuary is an affected area because of utilization activities in terrestrial area such as settlements, fishpond cultivation, and agriculture. Those activities play a significant role to decline in water quality including runoff of suspended solid in the area. Concentration of total suspended solid (TSS) drifting and floating to the estuary generates turbidity and siltation. The purpose of this study was to determine the concentration of TSS, changes in seacurrent patterns and distribution of TSS during high and low tide conditions in La Balano Estuary, Muna Regency. Five station points were determined through purposive sampling. Retrieval of water sample and oceanographic physical parameters were collected during low and high tide conditionwhich wasanalyzed using the Gravimetric method in Laboraroty. TSS distribution pattern was interpolated using Inverse Distance Weighted (IDW). Results showed that the concentration of TSS in La Balano Estuary ranged from $13.90-14.46 \mathrm{mg} / \mathrm{l}$ at high tide while in low tide, it ranged from 13.87 - $14.50 \mathrm{mg} / \mathrm{l}$. Seacurrent pattern was lead by alternatingtidal currents. When high tide, TSS was accumulated in surrounding of jetty while in low tide, suspended solid was settled at the river mouth. Based on the results, it can be concluded that distribution pattern of TSS was influenced by the movement of tidal currents and suspended soil of sedimen source was generated from the mainland.
\end{abstract}

Keywords : Total Suspended Solid, Tidal Seacurrent, Distribution Pattern, Estuary of La Balano River

\section{Pendahuluan}

Estuari merupakan badan air tempat terjadinya percampuran antara massa air laut dengan air tawar yang berasal dari daratan. Percampuran air di estuari ini dapat terjadi karena adanya turbulensi yang berlangsung secara berkala yang dipengaruhi oleh pasang surut air laut. Kondisi perairan sangat tergantung pada kondisi air laut dan air tawar yang masuk ke dalamnya. Semakin banyak konsentrasi Material Padatan Tersuspensi
(MPT) yang dibawa oleh air tersebut, maka semakin tinggi endapan lumpur di estuari (Nybakken, 1998).

MPT adalah semua zat padat (pasir, lumpur, dan tanah liat) atau partikel-partikel yang tersuspensi dalam air dan dapat berupa komponen hidup (biotik) seperti fitoplankton, zooplankton, bakteri, fungi, ataupun komponen mati (abiotik) seperti detritus dan partikel-partikel anorganik. Sebaran zat padat 
tersuspensi di laut antara lain dipengaruhi oleh masukan yang berasal dari darat melalui aliran sungai, ataupun dari udara dan perpindahan karena resuspensi endapan akibat pengikisan serta pasang surut, angin, arus laut, aktivitas manusia dan sebagainya (Tarigan dan Edward, 2003).

Sungai La Balano adalah salah satu sungai yang terdapat di wilayah Kecamatan Batalaiworu, Kabupaten Muna yang digunakan oleh para nelayan kecil sebagai jalur menuju laut. Perairan muara Sungai La Balano merupakan tipe estuaria campuran dimana sirkulasi perairannya dipengaruhi oleh air tawar dan air asin (Tarigan dan Edward, 2003).

Di sekitar Sungai La Balano terdapat kegiatan pemanfaatan ruang seperti pemukiman, budidaya tambak, perkebunan dan pertanian yang diperkirakan berperan besar pada terjadinya penurunan kualitas air. Konsentrasi MPT yang berlebihan di Muara Sungai La Balano dapat menyebabkan kekeruhan dan ancaman pendangkalan di wilayah pesisir muara sungai. Hal itu dapat menyebabkan terganggunya aktivitas pelayaran khususnya aktivitas di dermaga/pelabuhan Tempat Pelelangan Ikana (TPI) dan budidaya laut. Kegiatan tersebut juga dapat menghasilkan limbah bahan pencemar masuk ke dalam perairan yang dapat menyebabkan dampak negatif terhadap kondisi kehidupan perairan laut dan kerusakan lingkungan.

Berdasarkan hal tersebut diatas maka tujuan dari penelitian ini adalah untuk mengetahui konsentrasi MPT, mengetahui perubahan pola arus dan faktor yang mempengaruhi serta untuk mengetahui pola sebaran MPT di Perairan Muara Sungai La Balano saat kondisi pasang dan surut.

\section{Bahan dan Metode}

Penelitian ini dilaksanakan pada bulan Oktober 2018 di wilayah Perairan Muara Sungai La Balano, Kabupaten Muna, Sulawesi Tenggara. Selanjutnya analisis sampel air padatan tersuspensi dilaksanakan di Laboratorium Fakultas Perikanan dan Ilmu Kelautan Universitas Halu Oleo Kendari.

Kegiatan yang dilakukan pada tahap ini yaitu observasi lapangan yang dimanah untuk melihat dan mengetahui kondisi lapangan, penentuan titik stasiun, penentuan metode penelitian, survei awal lapangan serta penyiapan peralatan yang akan digunakan pada saat di lapangan.

Penentuan titik stasiun penelitian menggunakan metode purposive sampling yaitu menentukan stasiun dengan cara memilih titik lokasi yang dianggap mewakili tiap bagian dari muara Sungai La Balano, dengan memperhatikan pertimbangan kondisi serta keadaan dari daerah penelitian, posisi stasiun ditentukan dengan menggunakan alat GPS (Global Positioning System). Penentuan titik stasiun yang dimulai dari arah muara Sungai menuju ke arah laut. Penetuan titik stasiun pengambilan sampel didasarkan pada karateristik lingkungan sekitar area Tempat Pelelangan Ikan (TPI) yang dibagi menjadi 5 titik stasiun penelitian. Lokasi penelitian dapat dilihat pada Gambar 1.

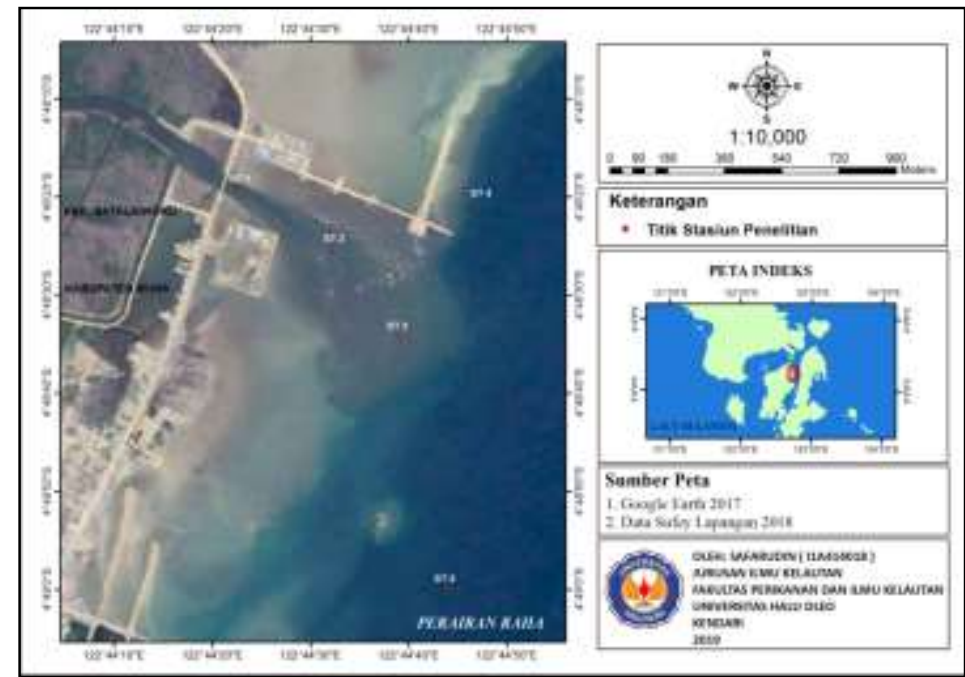

Gambar 1. Peta Lokasi Penelitian di Perairan Muara Sungai La Balano 
Pengambilan sampel air menggunakan botol sampel pada lapisan permukaan dengan kedalaman $\pm 1 \mathrm{~m}$ dari permukaan perairan. Sampel air diambil menggunakan water sampler dengan volume air yang diambil sebanyak $600 \mathrm{ml}$ dimasukkan ke dalam botol sampel, selanjutnya botol sampel dimasukkan ke dalam coolbox. Kemudian sampel dianalisis di Laboratorium Fakultas Perikanan dan Ilmu Kelautan, Universitas Halu Oleo. Analisis MPT dilakukan sesuai dengan metode Gravimetri.

Analisis sampel material padatan tersuspensi menggunakan metode Gravimetri, dimana untuk mengetahui sebaran nilai MPT di perairan, maka sampel yang diperoleh dianalisis dengan rumus menurut Badan Standarisasi Nasional Indonesia (2004) :

$\operatorname{MPT}(\mathrm{mg} / \mathrm{l})=\frac{(\mathrm{A}-\mathrm{B}) \times 1000}{\mathrm{C}}$

Keterangan:

MPT = Material Padatan Tersuspensi (mg/l

$\mathrm{B}=$ Berat Kertas Saring (mg)

A $\quad=$ Berat Kertas Saring + Residu Kering (mg)

$\mathrm{C} \quad=$ Volume Sampel Air (ml)

Pengukuran parameter kualitas lingkungan perairan yang diukur, meliputi: suhu, salinitas, kecerahan, dan kecepatan arus. Pengukuran dan pengamatan ini dilakukan secara langsung di lapangan di setiap stasiun pengambilan sampel air.

Kecepatan arus dihitung dengan menggunakan rumus persamaan sebagai berikut (Norhadi et al., 2015).

$\mathrm{V}=\frac{\mathrm{L}}{T}$

Dimana :

$\mathrm{V}=$ Kecepatan Arus (m/s)

$\mathrm{L}=$ Panjang Tali $(\mathrm{m})$

$\mathrm{T}=$ Waktu (s).

Data yang diperoleh dari hasil pengukuran di lapangan dan analisis material padatan tersuspensi (MPT) ditabulasikan dan diolah dengan Microsoft Excel. Untuk mendapatkan peta pola sebaran, data yang diperoleh diolah menggunakan metode interpolasi Inverse Distance Weighted (IDW). Kemudian data dianalisis secara deskriptif berdasarkan faktor-faktor oseanografi yang mempengaruhi.

\section{Hasil dan Pembahasan}

Sungai La Balano terletak di bagian Utara Kota Raha yang terdapat di wilayah Kecamatan Batalaiworu, Kabupaten Muna yang merupakan sebuah sungai yang muaranya sangat dipengaruhi oleh pasang surut air laut. Pada daerah muara sungai ini memiliki berbagai aktivitas masyarakat seperti digunakan sebagai jalur transportsi air dan pada sisi kiri muara Sungai La Balano terdapat lokasi pembangunan Dinas Perikanan, pembangunan TPI (Tempat Pelelangan Ikan) dan pembangunan dermaga TPI. Data pasang surut yang di peroleh dari data sekunder yang di ambil dengan menggunakan software Fising Point selama 30 hari pada bulan OktoberNovember yang di mualai pada pukul 00.00 WITA dengan interval waktu 1 jam. Kemudian dilanjutkan analisis dengan metode Admiralty untuk mendapatkan karakteristik konstanta harmonik pasang surut. Tinggi (High Water Level) $=372$. Perairan Muara Sungai La Balano mempunyai nilai formzahl sebesar 0.28 sehingga tipe pasang surut perairan tersebut adalah campuran condong ke harian ganda. Menurut Fadilah et al. (2014) tipe pasang surut berdasarkan bilangan formzahl 0.025 $<\mathrm{f} \leq 1.50$ adalah tipe pasang surut campuran dengan tipe ganda lebih menonjol (condong ganda) dimanah dalam sehari terjadi dua kali air pasang dan dua air kali surut. Tinggi pasang surut yang pertama berbeda dengan tinggi pasang surut yang kedua.Berdasarkan hasil nilai-nilai di atas maka diperoleh nilai Formzahl $=0.28$, Tinggi Muka Air Rata-rata (Mean Sea Level) $=168$, Muka Air Rendah (Low Water Level $)=-29$ Muka Air.

Tabel 1. Konstanta Harmonik Pasang Surut di Perairan Muara Sungai La Balano

\begin{tabular}{ccccccccccc}
\hline \multicolumn{10}{c}{ Kostanta Harmonik } \\
\hline & S0 & M2 & S2 & N2 & K1 & O1 & P1 & M4 & MS4 & K2 \\
\hline A $(\mathbf{c m})$ & 168 & 67 & 29 & 70 & 5 & 22 & 2 & 1 & 1 & 8 \\
G & & 110 & 100 & 56 & 289 & 358 & 289 & 351 & 358 & 100 \\
\hline
\end{tabular}




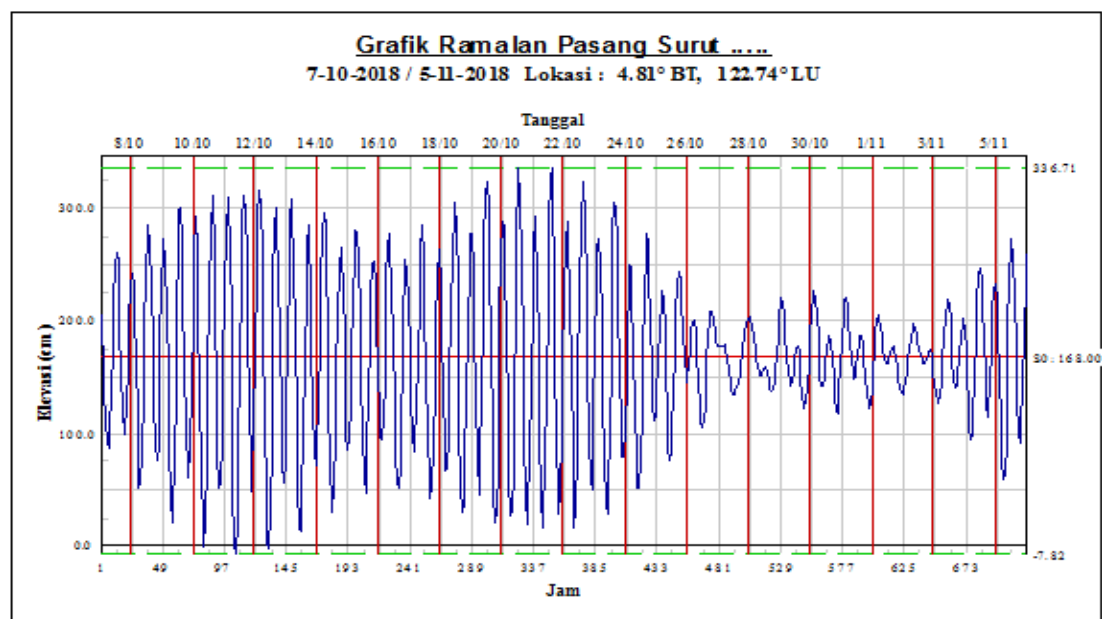

Gambar 2. Grafik Pasang Surut di Peraira Muara Sungai La Balano (Sumber: Pengolahan Data Pengamatan, 2018)

Tabel 2. Hasil Pengukuran Parameter Fisika Oseanografi di Perairan Muara Sungai La Balano

\section{Parameter}

\begin{tabular}{c|c|c|c|c|c|c|c|c|}
\cline { 2 - 9 } Stasiun & \multicolumn{2}{|c|}{ Suhu $\left({ }^{\circ} \mathbf{C}\right)$} & \multicolumn{2}{c|}{ Salinitas (ppt) } & \multicolumn{2}{c|}{ Kecerahan $(\mathbf{m})$} & \multicolumn{2}{c|}{ ecepatan Arus (m/ } \\
\cline { 2 - 10 } & Pasang & Surut & Pasang & Surut & Pasang & Surut & Pasang & Surut \\
\hline I & 31 & 30 & 32 & 31 & 3 & 2.7 & 0.045 & 0.068 \\
\hline II & 31 & 30 & 32 & 31 & 2.9 & 2.6 & 0.049 & 0.055 \\
\hline III & 32 & 31 & 32 & 31 & 2.5 & 2.2 & 0.05 & 0.048 \\
\hline IV & 32 & 32 & 33 & 33 & 2.4 & 2.3 & 0.054 & 0.05 \\
\hline V & 32 & 31 & 33 & 32 & 3.4 & 3.1 & 0.043 & 0.046 \\
\hline Rata-rata & 31.6 & 30.8 & 32.4 & 31.6 & 2.84 & 2.58 & 0.048 & 0.053 \\
\hline
\end{tabular}

Tabel 3. Kosentrasi MPT Kondisi Pasang dan Surut di Perairan Muara Sungai La Balano

\begin{tabular}{|c|c|c|}
\hline \multirow{2}{*}{ Stasiun } & \multicolumn{2}{|c|}{ Konsentrasi MPT $(\mathbf{m g} / \mathbf{l})$} \\
\cline { 2 - 3 } & Pasang & Surut \\
\hline I & 13.93 & 14.17 \\
\hline II & 13.98 & 14.04 \\
\hline III & 14.1 & 14.5 \\
\hline IV & 14.46 & 14.08 \\
\hline V & 13.9 & 13.87 \\
\hline Rata-Rata & 14.074 & 14.132 \\
\hline
\end{tabular}

Hasil penelitian pengukuran arah arus pada daerah penelitian pada setiap titik stasiun pengamatan yang dilakukan saat kondisi pasang, arus bergerak dari arah Tenggara ke Barat Laut dan Utara sedangkan saat kondisi surut arus bergerak dari arah Barat dan Barat Laut ke arah Tenggara dan Timur.

Material padatan tersuspensi (MPT) merupakan padatan yang tersuspensi di dalam air yang berupa bahan-bahan organik dan inorganik yang tidak terlarut dan tidak mengendap langsung, dapat disaring dengan kertas milipore yang berpori-pori (Subardjo et al., 2018). Berdasarkan nilai konsentrasi MPT yang disajikan pada Tabel 3 menunjukkan bahwa nilai konsentrasi MPT di lokasi penelitian saat kondisi pasang yaitu berkisar antara $13.90 \mathrm{mg} / \mathrm{l}-14.46 \mathrm{mg} / \mathrm{l}$, di mana konsentrasi MPT tertinggi saat pasang ditemukan pada stasiun IV sebesar 14.46 $\mathrm{mg} / \mathrm{l}$ sedangkan nilai konsentrasi MPT terendah ditemukan pada stasiun $\mathrm{V}$ yaitu $13.90 \mathrm{mg} / \mathrm{l}$. Nilai rata-rata MPT kondisi pasang $14.074 \mathrm{mg} / \mathrm{l}$. 


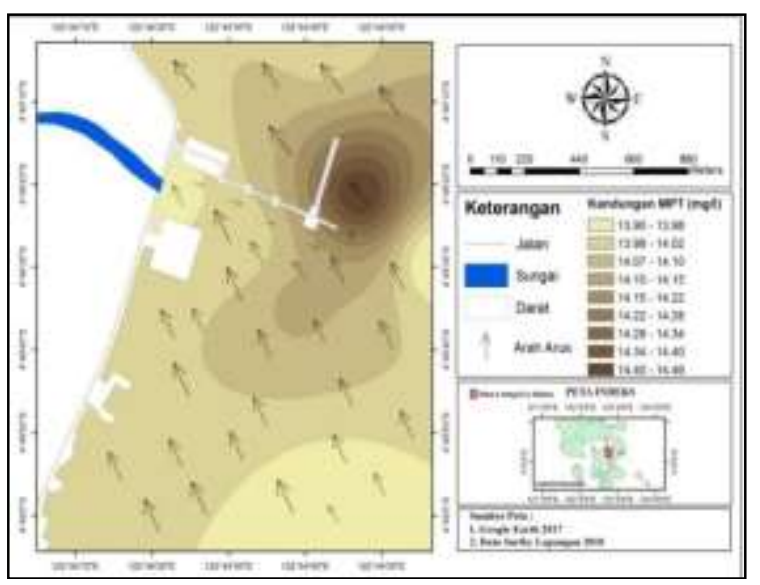

(a)

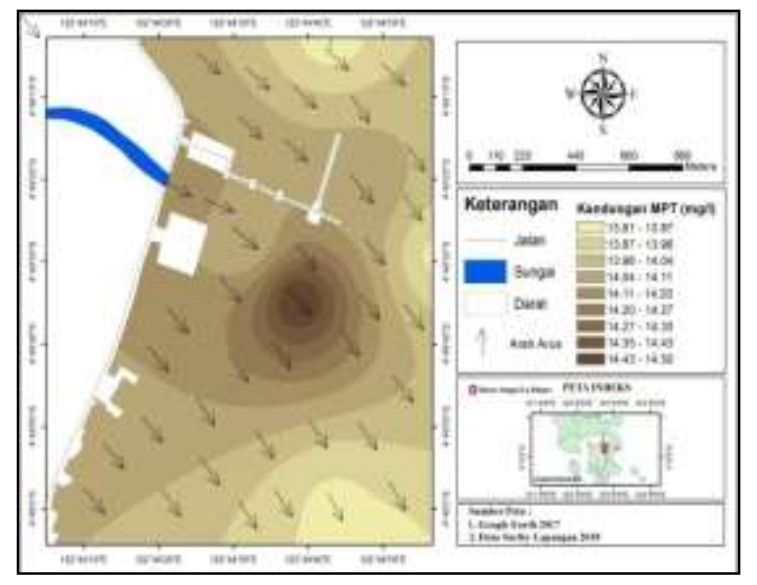

(b)

Gambar 3. Peta Pola Sebaran MPT dan Pola Arus di Lokasi Penelitian a). Kondisi Pasang, b). Kondisi Surut

Tingginya nilai konsentrasi MPT distasiun IV saat kondisi pasang karena letak stasiun berada di dekat muara sungai tepatnya di depan daerah kawasan pelabuhan dan Tempat Pelelangan Ikan (TPI). Di sekitar pelabuhan terdapat aktifitas pembagunan dermaga, sehingga hal ini dapat menyebabkan tingginya konsentrasi MPT di daerah tersebut karena akibat dari aktivitas pelabuhan serta adanya masukan sedimen yang ada di darat maupun sekitar sungai yang terangkut oleh aliran sungai. Pernyataan ini didukung oleh Pristiwan et al., (2015) yang menyatakan bahwa aktivitas manusia yang bersifat mencemari lingkungan turut menjadi faktor utama penyebab tingginya konsentrasi MPT. Hal ini juga sesuai dengan pernyataan Helfinalis (2005) yang menyatakan bahwa penyebab tingginya TSS salah satunya dipengaruhi oleh asupan material dari daratan yang terbawa melalui aliran sungai.

Sedangkan rendahnya konsentrasi MPT pada stasiun V karena letak lokasinya yang jauh dengan muara sungai yang berada di laut lepas yang relatife lebih dalam, sehingga konsentrasinya rendah karena jauh dari sumber material sedimen yaitu muara sungai, hal ini juga disebabkan oleh arah arus saat kondisi pasang yang bergerak ke arah Barat Laut (Darat) sehingga MPT yang berada di laut lepas akan terbawa arus hingga mendekati pantai. Hal ini didukung dengan hasil penelitian Millaty et al., (2015) yang menyatakan bahwa stasiun yang berada di perairan dalam memberikan pengaruh terjadinya penurunan MPT karena resuspensi sedimen dasar lebih kecil. Solihudin (2009) menambahkan bahwa arus laut yang terjadi baik diakibatkan oleh pasang surut maupun gelombang merupakan salah satu parameter di dalam mengontrol dinamika distribusi MPT di perairan karena keberadaan MPT di perairan mengapung (floating), sehingga pergerakannya tergantung dari arah arus.

Konsentrasi MPT saat kondisi surut di lokasi penelitian (Tabel 3) berkisar antara $13.87 \mathrm{mg} / \mathrm{l}-14.50 \mathrm{mg} / \mathrm{l}$. Nilai konsentrasi MPT tertinggi terdapat pada stasiun III yaitu sebesar $14.50 \mathrm{mg} / \mathrm{l}$ dan terendah terdapat pada stasiun $\mathrm{V}$ yaitu $13.87 \mathrm{mg} / \mathrm{l}$. Rata-rata konsentrasi MPT kondisi surut yaitu $14.123 \mathrm{mg} / \mathrm{l}$.

Tingginya nilai konsentrasi MPT pada stasiun III kondisi surut, disebabkan karena letak stasiun ini berada di muara Sungai La Balano sebagai akumulasi dan pengadukan material dari darat, di mana daerah tersebut tingkat pengadukannya lebih tinggi, sehingga perairan tersebut lebih keruh karena mendapat masukan MPT yang paling tinggi dibanding stasiun lainnya. Sedimen tersuspensi yang masuk ke muara sungai berasal dari darat maupun di sekitar sungai dipengaruhi arus serta pasang surut. Kondisi ini sesuai pendapat Dewanty et al., (2014) bahwa muara sungai membawa material sedimen dari darat, sehingga nilai konsentrasi yang berada di muara sungai lebih tinggi. Qualifa et al., (2016) menambahkan bahwa pengadukan sedimen dasar perairan terjadi pada perairan yang dapat mengalami pendangkalan yang dalam hal ini adalah 
muara sungai sehingga mengakibatkan nilai kandungan material padatan tersuspensi di daerah muara sungai juga tinggi.

Sedangkan rendahnya nilai konsentrasi MPT kondisi surut pada stasiun V disebabkan karena lokasi stasiun berada di laut lepas sebelah kanan muara Sungai La Balano, di mana konsentrasi MPT akan semakin rendah ke arah laut yang diakibatkan terjadinya pengenceran oleh air laut. Kondisi sesuai pendapat Irawati (2011) dan Winarsih et.al., (2016) yang menunjukkan bahwa konsentrasi TSS mengalami penurunan ke arah laut yang diakibatkan adanya pengenceran oleh air laut ketika material tersebut sampai di daerah laut. Jewlaika et al., (2014) menambahkan bahwa sebaran total suspended solid ini nilainya akan semakin rendah ke arah laut.

Berdasarkan hasil pengamatan dan analisis laboratorium yang disajikan pada Tabel 3 nilai konsentrasi MPT dilokasi penelitian, memperlihatkan bahwa nilai konsentrasi MPT saat kondisi pasang dan kondisi surut tidak begitu berbeda signifikan hanya saja konsentrasinya lebih tinggi saat kondisi surut disbanding saat kondisi pasang. Hal ini diduga karena saat kondisi surut bayak masukan MPT dari darat yang terbawah oleh aliran sungai yang dipengaruhi debit aliran sungai, sebaliknya saat kondisi pasang kurang bahan MPT dari sungai dan laut serta adanya pengenceran MPT lebih besar saat kondisi pasang, karena jumlah volume air saat pasang yang masuk ke perairan lebih besar dari pada saat kondisi surut. Sehingga konsentrasi MPT terukur lebih kecil. Hal ini diperkuat oleh Aryani et al., (2016) menyatakan bahwa konsentrasi sedimen tersuspensi sangat dipengaruhi oleh pasang surut air laut. Saat pasang konsentrasi sedimen akan menurun dan sebaliknya saat surut konsentrasi sedimen akan meningkat. Hal ini karena kedalaman aliran semakin besar saat air laut pasang yang mengakibatkan menurunnya konsentrasi sedimen atau dengan kata lain terjadi pengenceran terhadap sedimen. Nurhady (2008) menyatakan konsentrasi sedimen saat surut lebih tinggi dibandingkan pasang. Hal tersebut dinyatakan karena adanya pengenceran terhadap sedimen yang diakibatkan kedalaman aliran semakin besar saat air laut pasang sehingga konsentrasi sedimen menjadi menurun.

Berdasrkan hasil pengukuran lapangan arah dan pergerakan arus di lokasi penelitian saat kondisi pasang arus bergerak dari arah Tenggara menuju ke Barat Laut dan Utara (Daratan) (Gambar 3a) sedangkan saat kondisi surut arus bergerak dari arah Barat dan Barat Laut menuju ke arah Tenggara dan Timur (Laut) (Gambar 3b). Berdasarkan hasil pengamatan selama penelitian memperlihatkan bahwa pola arus di lokasi penelitian saat kondisi pasang dominan bergerak ke Barat Laut, sedangkan saat kondisi surut arus bergerak dominan ke arah Tenggara, dengan demikian dapat dilihat bahwa pola arus di lokasi penelitian dipengaruhi oleh pasang surut karena arahnya dominannya yang dua arah atau bolak balik. Hal ini didukung oleh Taohid et al., (2017) perairan yang dipengaruhi pasang surut maka arus pasut yang terjadi akan bolak-balik karena perbedaan tinggi dan fase pasut. .

Saat kondisi surut terjadi penumpukan MPT pada daerah muara sungai (Stasiun III) dengan nilai konsentrasi MPT sebesar 14.50 $\mathrm{mg} / \mathrm{l}$. Hal ini disebabkan oleh arus saat surut menuju ke arah Tenggara, dimana aliran sungai yang keluar menuju ke laut akan bertemu dengan arus laut yang menuju pantai. Kedua aliran yang berlawanan arah ini akan menyebabkan suatu tempat dimana kecepatan aliran adalah kecil akibat poses pengadukan oleh arus dan pasang surut, hingga menyebabkan turbulensi yang lebih maksimal dibanding saat kondisi pasang, sehingga sebagian besar sedimen mengendap.

Hal ini lah yang membuat terjadinya penumpukan sedimen di muara sungai lokasi penelitian dan akan dapat menyebabkan terjadi proses pendangkalan. Dimana muara Sungai La Balano dipengaruhi oleh pasang surut. Sarjono (2009) menyatakan bahwa lokasi muara sungai yang banyak dipengaruhi oleh aktifitas hidro oseanografi yang tinggi membuat muara sungai mengalami pendangkalan serta dapat menyebabkan terjadinya proses pengadukan sedimen dasar perairan yang juga turut berperan dalam meningkatkan nilai kekeruhan perairan. 
Tabel 4. Kesesuaian Nilai MPT Perairan Untuk Kepentingan Perikanan

\begin{tabular}{ccc}
\hline NO & Nilai MPT $(\mathbf{m g} / \mathbf{l})$ & Pengaruh Terhadap Perikanan \\
\hline 1 & $<25$ & Tidak berpengaruh \\
2 & $25-80$ & Sedikit berpengaruh \\
3 & $81-400$ & Kurang baik bagi kepentingan perikanan \\
4 & $>400$ & Tidak baik lagi bagi kepentingan perikanan \\
\hline
\end{tabular}

Perairan yang mengalami pendangkalan menyebabkan arus menuju pasang yang masuk ke arah hulu (sungai) tertahan dan berbenturan sehingga terjadilah proses pengadukan dimana sedimen yang telah mengendap teraduk kembali ke permukaan sehingga menyebabkan nilai konsentrasi material padatan tersuspensi di muara sungai menjadi tinggi (Newyeara et al., 2014). Menurut Simbolon et al., (2015) lokasi muara sungai yang dipengaruhi oleh arus dan pasang surut yang tinggi menyebabkan terjadinya proses pengadukan sedimen dasar perairan sehingga nilai konsentrasi di muara sungai tinggi dan juga berperan dalam meningkatkan nilai kekeruhan periran.

Pola sebaran MPT di lokasi penelitian mengikuti pergerakan arus laut yang ditunjukkan pada Gambar 5 di mana saat kondisi pasang arus menuju ke Barat Laut (Darat) dan sedimen tersuspensi tertekan kearah daratan, sedangkan saat kondisi surut arus mengarah ke Tenggara dan Timur (Laut) dan sedimen tersuspensi tertekan kearah muara sungai. Menurut Siswanto (2011) menyatakan bahwa beberapa parameter hidrooseanografi yang berpengaruh terhadap sebaran sedimen, diantaranya adalah arus dan gelombang. Purba et al., (2018) menyatakan bahwa kecepatan dan arah arus menentukan kandungan dan pola sebaran padatan tersuspensi di perairan selain cepat dan lemahnya arus baik pasang maupun surut.

Secara umum konsentrasi MPT di lokasi penelitian saat kondisi pasang hanya berkisar antara $13.90-14.46 \mathrm{mg} / \mathrm{l}$ dengan nilai rata - rata $14.074 \mathrm{mg} / \mathrm{l}$, sedangkan saat kondisi surut berkisar antara 13.87 - 14.50 $\mathrm{mg} / \mathrm{l}$ dengan nilai rata-rata $14.132 \mathrm{mg} / \mathrm{l}$, sehingga tidak menghalangi penetrasi sinar matahari yang masuk ke Perairan Muara Sungai La Balano. Nilai konsentrasi MPT di daerah penelitian ini masih di bawah ambang batas baku mutu air laut menurut Keputusan Menteri Negara Lingkungan
Hidup No. 51 tahun 2004 tentang baku mutu air laut, untuk biota laut (diperoleh nilai baku mutu MPT untuk kehidupan terumbu karang dan lamun $<20 \mathrm{mg} / \mathrm{L}$, sedangkan untuk mangrove $<80 \mathrm{mg} / \mathrm{L}$ ), baku mutu air laut untuk budidaya (diperoleh nilai baku mutu MPT $20 \mathrm{mg} / \mathrm{l}$ ) dan baku mutu air laut untuk perairan pelabuhan (diperoleh nilai baku mutu MPT $80 \mathrm{mg} / \mathrm{l}$ ), Berdasarkan hasil analisis MPT diatas menunjukan bahwa tidak ada yang melebihi nilai baku mutu tersebut. Oleh karena itu dapat disimpulkan bahwa kondisi MPT di lokasi penelitian secara umum masih di bawah baku mutu air laut atau masi memenuhi baku mutu perairan laut, sehingga masih layak untuk kehidupan biota air dan kegiatan perikanan seperti kegiatan budidaya, kegiatan wisata bahari dan pelabuhan karena belum melewati baku mutu.

\section{Kesimpulan}

Berdasarkan hasil penelitian yang telah dilaksanakan di Perairan Muara Sungai La Balano, maka dapat disimpulkan sebagai berikut :

1. Konsentrasi MPT di Perairan Muara Sungai La Balano saat kondisi pasang berkisar antara $13.90-14.46 \mathrm{mg} / \mathrm{l}$ dan kondisi surut berkisar $13.87-14.50$ $\mathrm{mg} / \mathrm{l}$, nilai MPT tertinggi berada di muara sungai $14.50 \mathrm{mg} / \mathrm{l}$ (Stasiun III) dan terendah berada di laut lepas yaitu $13.87 \mathrm{mg} / \mathrm{l}$ (Stasiun V).

2. Perubahan pola arus di Perairan Muara Sungai La Balano yaitu terjadi bolakbalik yang dipengaruhi oleh faktor pasang surut air laut.

3. Pola sebaran MPT di Perairan Muara Sungai La Balano mengikuti pergerakan pola arus dimana saat kondisi pasang arus menuju ke Barat Laut terjadi penumpukan MPT di sekitar pembangunan dermaga TPI sedangkan saat kondisi surut arus menuju ke Timur dan Tenggara terjadi penumpukan MPT di muara sungai. 


\section{Daftar Pustaka}

Aryani, R., Saputro S. dan Hariadi. 2016. Sebaran Material Padatan Tersuspensi Berdasarkan Pengaruh Arus dan Pasang Surut di Sekitar Perairan Muara Sungai Kapuas Kecil, Jungkat, Pontianak. Jurnal Oseanografi. Vol. 5 (4): $470-478$.

Badan Standarisasi Nasional Indonesia. 2004. Metode Pengujian Kualitas Fisika Air. Air dan Limbah - Bagian3 : Cara Uji Padatan Tersuspensi Solid (Total Suspended Solid, TSS) Secara Gravimetri. SNI 06-6989.3-2004, Hal $1-10$.

Dewanty, R., Zainuri, M., dan Setyawan, B. W. 2014. Distribusi Material Padatan Tersuspensi di Perairan Bengkulu. Jurnal Oseanografi. Vol. 3 (3):411 418.

Effendi, H. 2003. Telaah Kualitas Air Bagi Pengelolaan Sumberdaya dan Lingkungan Perairan. Penerbit Kanisius. Yogyakarta. $98 \mathrm{Hal}$.

Fadilah, Suripin dan Sasongko P. D. 2014. Menentukan Tipe Pasang Surut dan Muka Air Rencana Perairan Laut Kabupaten Bengkulu Tengah Menggunakan Metode Admiralty. Maspari Journal. Vol. 6 (1):1-12.

Helfinalis. 2005. Kandungan Total Suspended Solid dan Sedimen Dasar di Perairan Panimbang. Makara. Sains Vol (9) No 2. 8 Hal.

Irawati, N. 2011. Hubungan Produktivitas Primer Fitoplankton dengan Ketersediaan Unsur Hara Pada Berbagai Tingkat Kecerahan di Perairan Teluk Kendari, Sulawesi Tenggara. Tesis. Sekolah Pascasarjana Institut Pertanian Bogor. Bogor.

Jewlaika L., Mubarak dan Nurrachmi I. 2014. Studi Padatan Tersuspensi di Perairan Pulau Topang Kabupaten Kepulauan Meranti Provinsi Riau. Jurnal Perikanan dan Kelautan. Vol. 9 (2): 53-66. ISSN 0853-7607.

Keputusan Menteri Negara Lingkungan Hidup Nomor 51 Tahun 2004 Tentang Baku Mutu Air Laut. Jakarta.

Millaty, D., Muslim dan Prihatiningsih, R.W. 2015. Studi Sebaran Material Padatan Tersuspensi di Perairan Sebelah Barat Teluk Jakarta. Jurnal Oseanografi. Vol. 4 (4): 771 - 776.
Newyeara, J. E., Atmodjo, W dan Hariadi. 2014. Sebaran Sedimen Tersuspensi di Perairan Kamal Muara, Penjaringan, Jakarta Utara. Jurnal Oseanografi. Vol. 3 (2) Hal. 210 - 219

Norhadi, A., Marzuki, A., Wicaksono, L dan Yacob R.A. 2015. Studi Debit Aliran Pada Sungai Antasan Kelurahansungai Andai Banjarmasin Utara. Jurnal POROS TEKNIK Vol. 7 No. 1 Hal: 153 ISSN 2085-5761.

Nurhady, S. 2008. Simulasi 2-Dimensi Transpor Sedimen di Sungai Mesuji Provinsi Lampung. Skripsi. Jurusan Teknik Lingkungan. Fakultas Teknik Universitas Gadjah Mada, Yogyakarta.

Nybakken, J.W. 1998. Biologi Laut. Suatu Pendekatan Ekologis. Penerbit PT. Gramedia. Jakarta. 459 Hal.

Pristiwan, H., Anugroho, A dan Nugroho D. 2015. Pemetaan Muatan Padatan Tersuspensi di Perairan Muara Banjir Kanal Barat Semarang Menggunakan Data Satelit Landsat 8. Jurnal Oseanografi. Vol. 4 (1): 280 - 286.

Purba, H. R., Mubarak dan Galib, M. 2018. Sebaran Total Suspended Solid (TSS) di Kawasan Muara Sungai Kampar Kabupaten Pelalawan Provinsi Riau. Jurnal Perikanan dan Kelautan Vol. 23 (1) : 21-30.

Qualifa, F., Atmodjo, W dan Marwoto J. 2016. Sebaran Material Padatan Tersuspensi Di Perairan Muara Sungai Ketiwon,Tegal. Jurnal Oseanografi. Vol. 5 (1): $60-66$.

Sarjono, A. 2009. Analisis Kandungan Logam Berat $\mathrm{Cd}, \mathrm{Pb}$, dan $\mathrm{Hg}$ Pada Air dan Sedimen di Perairan Kamal Muara, Jakarta Utara. Departemen Manajemen Sumberdaya Perairan. Skripsi. Fakultas Perikanan dan Ilmu Kelautan. Institut Pertanian Bogor, Bogor.

Simbolon Y. M., Saputro S. dan Hariyadi. 2015. Distribusi Sedimen Tersuspensi Berdasarkan Arus Pasang Surut di Muara Sungai Kuto, Kabupaten Kendal. Jurnal Oseanografi. Vol. 4 (4): $731-740$.

Siswanto, A.D. 2011. Tingkat Konsentrasi Total Suspended Solid (TSS) sebagai Indikator Awal Kualitas Perairan di Perairan Selat Madura, Kabupaten Bangkalan. Prosiding. Seminar 
Nasional Biologi. FMIPA. Unesa. Surabaya.

Solihudin, Sari, M.E dan Kusumah, G. 2011. Prediksi Laju Sedimentasi di Perairan Pemangkat Sambas Kalimantan Barat Menggunakan Metode Permodelan. Jakarta. Buletin Geologi Tata Lingkungan. Vol. (21) No 3. 117 126.

Solihuddin, T. 2009. Pemanfaatan Citra Landsat Multitemporal untuk Memantau Konsentrasi Total Padatan Tersuspensi di Perairan Delta Cimanuk, Jawa Barat. Buletin Geologi Tata Lingkungan. Vol. 19 (3):107-116.

Subardjo, P., Suryo, D.A.A., Pratikno, I., Handoyo, G. dan Karlina Putri Diani, P.K. 2018. Distribusi Material Padatan Tersuspensi di Muara Sungai Sambas, Kalimantan Barat Buletin Oseanografi Marina . Vol 7 No 1:22-28 PISSN : 2089-3507 EISSN : 2550-0015.

Tarigan, M.S dan Edward. (2003). Kandungan Total Zat Padat Tersuspensi (Total Suspended Solid) di Perairan Raha, Sulawesi Tenggara. J. Makara Sains. Vol.7 (3). 109-119.

Taohid, A.R., Satriadi, A. dan Saputro, S. 2017. Studi Pola Arus Dan Sebaran Material Padatan Tersuspensi di Pantai Marina Ancol, Jakarta. Jurnal Oseanografi. Vol. 6 (1):116 - 123

Triatmodjo, B. 1999. Teknik Pantai. Penerbit Djambatan. Yogyakarta.

Winnarsih, Emiyarti dan Alirman Afu, L.O. 2016. Distribusi Total Suspended Solid Permukaan di Perairan Teluk Kendari. Jurnal Sapa Laut (Jurnal Ilmu Kelautan). Vol. 1 (2): 54-59. Ve-ISSN 2503-0396. 